\title{
Move to Online Learning during COVID-19 Lockdown: Pre-Service Teachers' Experiences in Ghana
}

\author{
Ugorji I. Ogbonnaya \\ University of Pretoria, South Africa \\ https://orcid.org/0000-0002-6243-5953 \\ Florence C. Awoniyi \\ Department of Teacher Education, School of Education and Leadership, \\ University of Ghana, Legon, Accra, Ghana \\ https://orcid.org/0000-0001-9806-1837 \\ Mogalatjane E. Matabane \\ University of Pretoria, South Africa \\ https://orcid.org/0000-0001-7953-6729
}

\begin{abstract}
The coronavirus pandemic (COVID-19) has brought another dimension to teaching and learning across the levels of education. The lockdown imposed in many countries to curtail the pandemic forced many institutions of learning to shift to the online mode of teaching and learning. Using a descriptive survey research design, this study explored the online learning experiences of pre-service teachers at a Ghanaian university during the COVID-19 lockdown. The study focused on the pre-service teachers' preparedness for online learning in terms of their digital literacy and technological devices used for online learning, their positive online learning experiences, and the challenges they encountered learning online. The findings suggested that the pre-service teachers were digitally literate and mostly accessed online learning using smartphones. Besides, online learning enabled them to communicate and collaborate actively with their course mates and lecturers. It was found that the flexibility of online learning increased the students' motivation to learn. However, poor internet connectivity, the high cost of data, erratic power supply, lack of appropriate devices, inability to effectively manage their time, and family interruptions were some of the challenges experienced by the pre-service teachers.
\end{abstract}

Keywords: Coronavirus; COVID-19; E-learning; online learning; preservice teachers 


\section{Introduction}

The coronavirus pandemic (COVID-19) has brought another dimension to teaching and learning across the spectra of educational levels and systems in a way that was never envisaged (Goh \& Sandars, 2020; Tanabe, 2020). To minimize the loss of teaching and learning time due to the lockdown imposed in many countries to curtail the spread of the pandemic, many institutions of learning adopted online modes of teaching and learning (Burgess \& Sievertsen, 2020; Rose, 2020). Most of these institutions were unprepared (both in material and human resources) for the unprecedented online teaching delivery, and most students were mentally and materially unprepared for the switch to online learning. Many teachers and lecturers have never been formally trained to teach online, neither have students been trained or had prior experience of learning online. Hence, most institutions, lecturers, and students were caught off-guard by the sudden radical move to online education.

Effective engagement in online teaching and learning requires some necessary information and communication technology infrastructure (hardware and software) that most colleges and universities, especially in developing countries, might not have. It requires teachers' and lecturers' knowledge and skills of not only computer operations but also of the platforms used for online teaching and learning. However, at many institutions of learning in Africa, some teachers and lecturers do not have enough knowledge of how to use a computer, and many might not know how to teach using online platforms. Additionally, most of the students might not own computers (desktop or laptop) nor smartphones to enable them to access online learning. Besides, lack of or erratic power supply and access to the internet could be other challenges many people in some parts of Africa experience. Hence, meaningful online teaching and learning during the pandemic lockdown was a serious challenge to many students and teachers in Africa. This study explored the online learning experiences of pre-service teachers at a Ghanaian university. More specifically, it explored the students' preparedness for online learning concerning their digital literacy and ownership of technological devices, positive online learning experiences, and challenges encountered when learning online during the COVID-19 lockdown.

\section{Background}

Online learning is a complex term and there have been extensive debates about its standard definition (Halverson \& Graham, 2019). According to Watson (2008), there is no single definition of online learning. In its broadest sense, online learning is any access to learning through the use of some technology (Kalpokaite \& Radivojevic, 2019; Mahama, 2016; Watson, 2008). Both Watson (2008) and Mahama (2016) describe online learning as a version of distance learning, which improves access to educational opportunities for students who cannot attend the traditional face-to-face classroom tuition.

Enrolments for online learning expanded rapidly in higher education in the last two decades as the online mode of learning appeals to a diverse population of students with different needs that traditional face-to-face classes are incapable of meeting (Thomas, 2010). The growth of online learning not only enables opportunities for flexible learning environments but is a global initiative to 
provide quality education for all students, irrespective of their location (Casey, 2008). Proponents of online learning suggest that the quality of online learning is embedded within the method of delivery, asserting that the quality of instructions impacts learning outcomes (Figueroa et al., 2020; Mahama, 2016).

Online learning has been very effective for self-regulated learners. According to Thompson (2010, p. 24), "Online learning is more self-guided." The ability to selfregulate one's learning is critical in online learning as self-regulation allows students to use various metacognitive and cognitive strategies to accomplish learning objectives and goals (Greene \& Azevedo, 2010; Sealander, 2016). Online learning allows students to work at a place and time compatible with their learning needs and enables students to have sufficient time to focus on content and not on issues like traffic and other problems that may arise in the traditional classroom environment (Hartini et al., 2020; Thomas, 2010).

Online learning not only offers flexibility in terms of time and place but also provides students with expanded opportunities to register for credit-bearing courses at universities and colleges while they are still at secondary school (Shea \& Bidjerano, 2014). Online learning is an excellent platform to allow master teachers to teach students from different schools and opens pathways to learning for more rural students from poor socio-economic districts with unqualified and under-qualified teachers. Thus, teaching and learning online creates educational opportunities for individuals who may have faced unsurpassable barriers to study through traditional face-to-face learning (Sealander, 2016; Watson, 2008).

While there are many benefits of online learning, the absence of quality interaction when learning online can negatively affect some aspects of learning, as social and emotional aspects of learning are equally important as technical information (Donlevy, 2003; Traxler, 2018). Contrary to this view, some researchers (e.g. Fogel \& Nehmad, 2009; Ogbonnaya, 2019) argue that the use of social media platforms such as Twitter, WhatsApp, Facebook, and LinkedIn play a critical role in providing students with opportunities for interactions and expressions of ideas. Thus, social media networks play an essential role in reshaping traditional faceto-face education systems by allowing students to collaborate and share information through audio and virtual communication. Effective interaction and collaboration amongst students provided by online learning platforms are in line with Vygotsky's theory which focuses on the sociocultural perspective, suggesting that cognitive growth is highly influenced by society and culture (Vygotsky, 1962). Thus, as Ferdig (2007) posits, social media networks promote interaction between learners, and improves active learning in the student-centred constructivist environment.

While Ferdig (2007) argues that social media allows effective communication between faculties and students with students getting to know their lecturers better, he also warns of the likelihood of lecturers losing professionalism as students delve into their postings and personal profile information. According to Casey (2008), Straub (2009), and Figueroa et al. (2020), while much is known about the outcomes and characteristics of students who take online courses, less is known about their experiences. 


\section{Objective of the study}

The objective of this study was to explore pre-service teachers' online learning experiences during the COVID-19 lockdown concerning their preparedness for online learning in terms of their digital literacy and use of technological devices for online learning, their positive online learning experiences, and the challenges they encountered learning online. The study was expedient because the preservice teachers of today are the classroom teachers of tomorrow. There is the possibility that education will mainly be online in the near future, hence the need to explore pre-service teachers' online learning experiences to understand how to help them to learn online and prepare them to effectively teach online in the future. The pre-service teachers' experiences might help them understand the possible struggles of their potential students, thereby helping them to perhaps accomodate any future students' challenges. Besides, studies are yet to report the online learning experiences of pre-service teachers in a pandemic situation such as that of COVID-19.

\section{Methodology}

\subsection{Research design and sample}

This study used a descriptive survey research design which describes the opinions of the pre-service teachers regarding their online learning during the COVID-19 lockdown. The design involves the collection of data as presently constituted to describe a phenomenon, without a conscious effort to control any variables (Creswell \& Creswell, 2018; Dempsey, 2018). The participants were the pre-service teachers (faculty of education undergraduate students) at a university in Ghana. The university was purposely chosen because it is generally believed to be the most technologically advanced public university in Ghana and therefore expected to be more adaptive to the reality of online learning. It is also renowned for its academic excellence. Consequent to the lockdown in the country due to the COVID-19 pandemic, the university switched to an online mode of teaching and learning to complete the academic work for the semester. A convenient sampling technique was used to select the 300 third year level students who could easily be reached through some of their online courses. A sample of 147 pre-service teachers (Table 1) participated in the study. Descriptive statistics (frequencies and percent) were used to analyse the data from Likert scale type of questions while thematic analysis (Clarke \& Braun, 2013) was used to analyse data from the openended questions.

Table 1: Demographic profile of students

\begin{tabular}{lcc}
\hline Variables & Frequency & Percentage \\
\hline Gender & & \\
Male & 57 & 38.8 \\
Female & 87 & 59.2 \\
*Not indicated & 3 & 2.0 \\
Total & 144 & 100.0 \\
Age & & \\
$15-20$ & 26 & 17.7 \\
$21-25$ & 111 & 75.5 \\
$26-30$ & 10 & 6.8
\end{tabular}




\begin{tabular}{ccc}
$31-40$ & 0 & 0 \\
Over 40 & 0 & 0 \\
Total & 147 & 100.0 \\
\cline { 2 - 3 } *Three of the respondents did not indicate their gender
\end{tabular}

\subsection{Data collection instrument}

Data were collected using an online survey questionnaire. The questionnaire comprised 35 items. It was divided into four sections. Section A had two items dealing with the demographic data (gender and age) of the students. Section B consisted of eight items that dealt with their digital literacy and devices for online learning. Section $\mathrm{C}$, which focused on their online learning experiences, had 23 items. The students were expected to respond to the 23 items by expressing their level of agreement, or otherwise on a four-point Likert scale (strongly agree, agree, disagree, and strongly disagree). The last section of the questionnaire had two openended questions on the positive experiences and challenges regarding online learning - these items allowed the students to express their opinions in their own words. The instrument was developed from items used in online course evaluations and from some experienced education evaluation researchers. The items were reviewed and edited by some scholars. The reliability of the instrument, namely internal consistency, was established using Cronbach alpha. A value of 0.926 was obtained, meaning that the instrument could be judged reliable (George \& Mallery 2003). The link to the survey questionnaire was sent to the students via the learning management system.

\section{Findings}

The findings of this study are presented and discussed according to the themes: students' digital literacy, online learning devices, time spent on online learning, positive experiences, and online learning challenges.

\subsection{Students' digital literacy, devices, and time spent on online learning Digital literacy}

To delineate the students' digital literacy, they were asked to rate their digital literacy by choosing from excellent, very good, good, adequate, limited, poor, and not sure. Out of the 147 students that attended to the rating, 22 respondents, representing 15\%, rated their digital literacy excellent; 47 (32\%) rated it very good; $53(36 \%)$ rated it good; $10(7 \%)$ rated it adequate; $10(7 \%)$ rated it limited, and five $(3 \%)$ rated it poor. Thus, the findings showed that the students were digitally literate.

\section{Online learning devices}

The students were asked to indicate the devices they used to connect to the internet for their online learning, the devices they owned personally, and the devices and online platforms they found the most valuable for their online learning.

Regarding the devices they used to connect to the internet for their online learning, 134 (92\%) students used smartphones; 74 (51\%) used laptops; 10 (7\%) used tablets; and only five (3\%) used a desktop computer. It could be seen that the 
total frequency (223) was above the number of respondents (147). This is an indication that some of the students used more than one device for their online learning.

Out of the 146 students that responded to the ownership of the devices item of the questionnaire, 143 (98\%) owned a smartphone; 74 (51\%) owned a laptop; $14(10 \%)$ owned a tablet, and two (1\%) owned a desktop computer. Regarding the devices used to connect to the internet, 83 (56\%) used their smartphone for connection; 42 (29\%) used mobile phone hotspots; 19 (13\%) used Wi-fi routers, and three $(2 \%)$ used modems.

The students were also asked to indicate the platform they found most valuable for their online learning. Seventy-two (49\%) of the respondents found both the Zoom and Sakai learning management systems worthwhile. This was followed by WhatsApp, valued by $40(27 \%)$ students, while Screencast, Google meet, and Google classroom were found most valuable by seven (5\%) of the students. Furthermore, students were asked to list the tools they found the most valuable for their online learning. As many as 58 (39\%) valued Forum; Chatroom 51 (35\%); Test and Quizzes 49 (33\%); Commons 7(5\%); Zoom four (3\%); Sakai three (2\%), lecture videos two (1\%), and WhatsApp one (less than 1\%). One of the respondents did not value any tool for online learning. The student declared, "I found none valuable because it is not easy for me to afford the technology and data for it."

\section{Time spent on online learning}

The number of hours of online lectures per week received attention from the 147 students. Twenty-four students, representing $16 \%$, received lectures for one to two hours per week; 38 (26\%) for three to four hours per week; $36(24 \%)$ for five to six hours per week; 21 (14\%) and 28 (19\%) for seven to eight hours, and more than eight hours per week, respectively. Out of the 146 students who responded to the item on the number of hours spent learning online daily; 73 (50\%) spent one to two hours; 41 (28\%) spent three to four hours; 25 (17\%) spent five to six hours; $4(3 \%)$ spent seven to eight hours, and $3(2 \%)$ spent more than eight hours learning online daily.

\subsection{Students' positive online learning experiences}

The participants were asked to share their positive experiences of learning online in an open-ended question. The data were coded for common themes amongst the responses. Although the authors planned to use predetermined codes, some codes emerged during the data analysis (Creswell \& Creswell, 2018), thus, a combination of emerging and predetermined codes were used. There was also an inter-coder agreement where two or more coders agree on codes used for the same statement. The coding occurred in two phases. The first phase identified overarching themes in the data. The second phase identified sub-themes within the overarching themes. In this case, the focus was on four overarching themes: active learning and collaboration, flexibility, self-regulated learning, and improved digital communication skills. 


\section{Active learning and collaboration}

While many studies highlighted a lack of collaboration and active learning as a deficit for online learning (Crosta, 2016), in this study, there was high active engagement and collaboration among students. One hundred and fifteen (115) participants, representing $78 \%$, reported that online learning enabled them to communicate actively with classmates and they were free and comfortable to ask questions to fellow students and lecturers. Angela stated, "During online learning, one can easily ask questions without timidity or fear, it encourages me to ask questions since I won't see any student." The participants also reported that learning online allowed them to hear the voices of other students who were mainly quiet during face-to-face interactions. As George reported, "I got to know many students' views on topics that if it were to be the face-to-face class, they wouldn't have contributed."

\section{Flexibility}

The self-pacing nature of online learning increased students' motivation and satisfaction. The most frequently reported positive aspect of online learning was the flexibility of time and place to learn. One hundred and twenty-one (121) participants, representing $82 \%$, reported that they enjoyed online learning as they had a choice of places to learn and time compatible with their learning needs. According to Sam, "Lecture videos sent by the lecturer can be replayed at any time". The view was also shared by Lesedi, "I could go back to the chatroom to see all that we've discussed to get myself abreast of the topic."

\section{Self-regulated learning}

The ability to self-regulate and acquire independent learning skills is crucial at university (Mahama, 2016; Zimmerman, 2002). While being able to regulate oneself is not a mental ability or an academic performance skill, it is a critical "selfdirective process in which learners transform their mental abilities into academic skills" (Zimmerman, 2002, p. 3). In this study, 112 participants, representing 76\%, indicated that they enjoyed online learning because it encouraged them to take control of their learning and continuously evaluate their progress. According to Anita, "Online learning taught me that I don't have to be taught to learn, one could check many resources from YouTube, and so on." Thus, the participants in the study reported online learning as an opportunity to take ownership of and self-direct their learning.

\section{Improved digital communication skills}

In this study, 108 (72\%) respondents found online learning improved their digital communication skills and appreciation of using technology to learn. According to Mensah, "Learning online has enhanced both my typing and presentation skills. I have learned how to use various learning platforms." Rose and Annan had a similar experience, Rose said "it helped me enhance my presentation skills", while Annan said, "online learning has helped with constant communication between students and lecturer to facilitate learning."

\subsection{Challenges to the students' online learning}

Amidst the positive online learning experiences that the participants in this study had during the COVID-19 pandemic lockdown were some challenges they encountered with online learning. The students were asked an open-ended 
question to indicate the challenges they faced with online learning. Their responses to the question were analysed to identify common themes that emerged. The themes identified were: internet connectivity, cost, power (electricity) outage, devices, IT knowledge, time management, and family interruptions.

\section{Internet connectivity}

The study revealed that most of the respondents (105 - 71\%), encountered challenges in learning online that were related to internet connectivity. The internet connectivity challenges ranged from a slow internet network connection to a complete internet network failure. Kofi expressed that "unstable internet connectivity is one of my biggest problems." Similarly, Rose said that "the network wasn't stable" and Kwado noted, "the network the school gave us isn't working in my area." Another respondent expressed how internet connectivity leads to the digital divide between people in different cities and towns. According to the respondent, "The internet connectivity at my area is so bad to the extent that sometimes I have to travel to another town to do my quizzes or submit assignments which also affects my income."

\section{Cost}

The cost of data to engage in online learning was found to be another challenge experienced by some of the students. Even though Vodafone $\odot$ provided 5GB of data monthly to the students and lecturers to support online teaching and learning during the lockdown, the data were insufficient for some of the students. Hence, they had to buy more data for their online learning. Kwasi stated, "I' $m$ not able to afford data anytime, and the data given by the university finishes in a week." In all, 50 students (34\%) found the cost of data to access the internet a challenge they encountered to engaging effectively in online learning.

\section{Power (electricity) outage}

In most developing countries, including Ghana, the power supply is very erratic (Atta-Obenga \& Dadzie, 2020). However, contrary to expectation, only five respondents (constituting less than $4 \%$ of the participants) in this study reported that power outages was a challenge to their online learning during the COVID-19 pandemic lockdown.

\section{Devices}

Some of the respondents (9) did identify having challenges relating to a device to access online learning. Pointing out the challenge, one student said, "I have faced many challenges in terms of the digital device to use." Another respondent opined that, "I did not have a laptop and a good phone with enough space." Most of the students stated that they used only their smartphones to access the internet for their online learning. As a result of this, one student said, "because I use only the phone for everything, I sometimes miss information." Similarly, another student said that "some of the learning tools such as go-to-meeting app [were] not compatible with my tablet."

\section{Time management}

Time management was a challenge experienced by some of the respondents in this study. Thirty-three respondents (approximately 22\%) stated that they found 
it challenging to manage their time with online learning. One student said that it was difficult for her to allocate time for her studies, while another student said that online learning was time-consuming. Yet another student commented that different assignments from different lecturers made it difficult for her to manage her time effectively.

\section{Interruptions from family members}

Interruptions from family members and chores at home challenged some of the students' online learning. This view was expressed by seven participants as a challenge they encountered. Akuba said, "Parents don't even care they still give us a heap of chores to do, and it's irritating," while Kwami said, "interruption from family members" was a challenge to his learning online during the lockdown.

\section{Discussion of findings}

It was found that the participants in this study were digitally literate and most owned smartphones that they used for online learning. Hence, it could be said that digital illiteracy was not a threat to their online learning. Also, the portable nature of smartphones and their easy internet access might have helped the participants spend more time (at least one hour a day) learning online. However, the use of smartphones by most of the participants for their online learning probably impacted negatively on the online learning experiences of some of them. As observed by Morgan (2015), the use of smartphones can distract students from learning as they can easily switch over to social networks and other non-learning related websites. Besides, the use of mobile phones for online learning by most of the participants might have also contributed to some of their internet connectivity issues and other challenges they experienced with access to online learning platforms. While most mobile phones have great features for accessing the internet, some of them might not have the capabilities to access some of the online learning platforms.

Most participants in this study reported active engagement and collaboration as part of their positive experiences of online learning. This finding is contrary to the lack of collaboration and active learning in online learning reported in some previous studies (Crosta, 2016; Gilbert, 2015). The active learning opportunities reported by most of the respondents in this study suggest that online learning eliminates some barriers that limit participation during face-to-face instruction. As observed in some past studies, online learning allows students to easily interact and build communities, even when they are a thousand miles away (Brown, 2001; Tang \& Lam, 2014).

The result of this study indicates that $82 \%$ of the participants found online learning flexible. The students reported being able to replay the lecture videos at times convenient to them and that put them in charge of their learning as they could work at their own pace. The flexibility of online learning could have accounted for $76 \%$ of the students reporting that online learning made them take control of their learning. This finding corroborated the view of Casey (2008) that the most important characteristic of online learning is that it is flexible and student-centred. This view is also corroborated by Arkorful and Abaidoo (2015), 
who suggest that students perform better during online courses because they support student-centred instructional strategies and are flexible with time and place of study.

Another major positive of the online learning experience found in this study was students' improved digital communication skills reported by $72 \%$ of the respondents. The world revolves around communication, and digital communications have revolutionised and changed traditional communication both personally and academically (Berry \& Fagerjord, 2017; Waisbord, 2019). The need for students to hone their communication skills and exchange information meaningfully and on digital platforms is a critical skill in the 21st century. The students' improved digital communication skills reported in this study corroborated with the view of Kelentrić et al. (2017) that frequent digital communication not only helps students to become better acquainted with the forms of communication required by various professional and academic disciplines, but also enables students to think critically and construct new knowledge.

Poor internet connectivity was one of the major challenges found in this study that the students encountered in online learning. This corroborated the findings of some recent studies (for example, Atta-Obenga \& Dadzie, 2020; Bekoe et al., 2018; Mahama, 2016) that poor internet connectivity poses a challenge to internet usage in some parts of Ghana. The finding also corroborated the view of Narh et al. (2019) that poor internet connectivity is a challenge to e-learning in Ghana. Four years ago, Baylon and Antwi-Boasiako (2016) acknowledged that "Ghana also has a significant urban-rural digital divide, with the majority of the country's Internet connectivity (and especially faster fibre-optic connections) concentrated in the capital city of Accra and other large cities" (p. 2). The findings of this study confirmed that the digital divide still exists in Ghana, as is the case in most African countries.

The cost of data for online learning was found to be a challenge to the students' online learning in this study. Though the students were given some free data, it was not enough for most of them and some could not afford to buy additional data for their learning. This agreed with some earlier studies (e.g. Atta-Obenga \& Dadzie, 2020; Baylon \& Antwi-Boasiako, 2016; Mahama, 2016) that the cost of internet access is unaffordable to many in Ghana.

While power outages could be a major challenge to online learning (Atta-Obenga \& Dadzie, 2020), only a few of the participants in this study reported power outages as a challenge to their online learning. This could be because most of the participants used smartphones for online learning, so they were able to continue their learning even when there were power outages - using stored energy in their phone batteries or power banks. Similarly, a few participants reported challenges relating to devices for online learning. This challenge might have been because not all technological devices work well with certain online learning platforms as affirmed by Orlando and Attard (2015), that "teaching with technology is not a 
one size fits all approach as it depends on the types of technology in use at the time and also the curriculum content being taught" (p. 119).

Time management and interruptions from family members were found to be other challenges the students encountered in online learning. In agreement with these findings, students' inability to manage their time effectively when learning online has been found in other studies to be a challenge to some students (Roper, 2007; Yen et al., 2016). Some of the students' time management challenges were not unexpected because they were accustomed to face-to-face learning, where the time allocated to learning activities is predominantly controlled by their learning institutions. Similarly, lack of concentration due to distractions from family members and family responsibilities has been found in some previous studies to be a challenge to meaningful online learning (Figueroa et al., 2020; Kara et al., 2019). This could even be more pronounced during the COVID-19 pandemic lockdown when most family members were together at home over a long period.

\section{Conclusion}

This study explored the online learning experiences of pre-service teachers at a Ghanaian university concerning the students' preparedness for online learning in terms of their digital literacy and ownership of technological devices, positive online learning experiences, and challenges encountered while learning online during the COVID-19 lockdown. The study found that the students were digitally literate and that they were very aware of their level of digital literacy. Most of the students used smartphones to learn online and this limited their online learning activities. It was also found that online learning enabled them to communicate and collaborate actively with course mates and lecturers. Besides, the flexibility of online learning increased students' motivation to learn. However, low internet connectivity, cost of data, regular power (electricity) outages, lack of appropriate devices, time management, and family interruptions were some of the challenges experienced by the pre-service teachers.

\section{Implications of the findings and recommendations}

Lecturers and students need to keep pace with new online learning technologies

In a recent study, Ogbonnaya (2019) advocates the upskilling of students and faculties for effective teaching and learning using educational technologies. This upskilling is needed now more than ever. Various information and communication technologies are at the fulcrum of online teaching and learning. Most of the participants in this study revealed having challenges with the technology/devices used for online learning. We, therefore, recommend that lecturers and students be regularly trained to ensure that they are well-skilled on how to use technology to teach and learn. Lecturers and students need to be knowledgeable about using various information and communication technology platforms, not only in the face-to-face teaching and learning mode, but also in blended and fully online learning modes. This will make it easy for lecturers and students to quickly adjust to the needs of any teaching and learning mode that may arise. 


\section{Need for a rethinking of the education model}

To all stakeholders in education, especially in Africa, the COVID-19 pandemic has underscored the need for a rethink of the teaching and learning models in the current century. It is evident that the education landscape is no longer what it used to be in past decades, hence, there is a need for a paradigm shift in our philosophy of education.

\section{Investment in technology infrastructure and training}

The study revealed that most participants had challenges learning online because of a shortage/lack or inefficient infrastructure to engage in meaningful online learning. Most of the students accessed online learning via smartphones. Smartphones may not offer the flexibility and capability needed for meaningful online learning. Hence, we further recommend that learning institutions and the government invest more into acquiring relevant infrastructure to enhance online learning and teaching. These may include high-speed internet devices, computers, and tablets to enable easy and fast access to online learning materials and platforms.

\section{Training student on time management}

This study showed that some students lacked time management skills. Hence, there is a need for students to be helped to develop time management skills/strategies to enable them to effectively self-regulate their online learning.

\section{Providing students with devices and data}

Furthermore, we recommend that the government of Ghana and learning instituions consider finding ways to provide students with devices and sufficient data for online learning. Providing students with devices and data has minimized students' online learning challenges during the COVID-19 crisis in some countries (Radha et al., 2020). Learning institutions could also make devices part of the tuition package to ensure that every student has a device upon registration.

\section{Limitations of the study}

Just about $50 \%$ of the third-year pre-service teachers participated in the study. Hence, there is the possibility that those who did not participate in the study had a different experience with online learning from those who participated. Hence, the findings might have been different if all the students participated in the study. Besides, the participants were third-year students from one university, the online learning experiences of students in different levels of study and from different institutions might differ from the experiences of the students in this study. We, therefore, suggest that the finding of this study be interpreted considering the context.

\section{References}

Arkorful, V., \& Abaidoo, N. (2015). The role of e-learning, advantages and disadvantages of its adoption in higher education. International Journal of Instructional Technology and Distance Learning, 12(1), 29-42.

Atta-Obenga, L., \& Dadzie, P. S. (2020). Promoting sustainable development goal 4: The role of academic libraries in Ghana. Information \& Library Review, 52(3), 177-192. https://doi.org/10.1080/10572317.2019.1675445 
Baylon, C., \& Antwi-Boasiako, A. (2016). Increasing internet connectivity while combatting cybercrime: Ghana as a case study. The Centre for International Governance Innovation and Chatham House.

Bekoe, S., Atiso, K., Ayoung, D. A., Dzandu, L., \& Kumangkem, K. K. (2018). Examining internet usage patterns on socio-economic benefits of marginalised communities: The case of community information centres in Ghana. Library Philosophy and Practice (e-journal), 1870, 1-25.

Berry, D. M., \& Fagerjord, A. (2017). Digital humanities: Knowledge and critique in a digital age. Polity Press.

Brown, R. E. (2001). The process of community-building in distance learning classes. Journal of Asynchronous Learning Networks, 5(2), 18-35. http:/ / dx.doi.org/10.24059/olj.v5i2.1876

Burgess, S. \& Sievertsen, S. S. (01 April 2020). Schools, skills, and learning: The impact of COVID-19 on education. VOX, CEPR Policy Portal. Retrieved from https://voxeu.org/article/impact-covid-19-education

Casey, D. M. (2008). The historical development of distance education through technology. TechTrends, 52(2), 45-51. https:/ / doi.org/10.1007/s11528-008-0135-z

Clarke, V., \& Braun, V. (2013). Teaching thematic analysis: Overcoming challenges and developing strategies for effective learning. Psychologist, 26(2), 120-123.

Creswell, J. W., \& Creswell, J. D. (2018). Research design: Qualitative, quantitative, and mixed methods approaches ( $5^{\text {th }}$ ed.). Sage Publications, Inc.

Crosta, L. (2016). The online learning environment: A personal experience of collaboration. In S. J. Cranmer, N. Bonderup-Dohn, M. De Laat, T. Ryberg \& J-A. Sime (Eds.), Proceedings of the Tenth International Conference on Networked Learning 2016: Looking back - moving forward (pp. 1-6). Lancaster University.

Dempsey, P. R. (2018). How LIS scholars conceptualize rigor in qualitative data. Libraries and the Academy, 18(2), 363-390. https:/ / doi.org/10.1353/pla.2018.0020

Donlevy, J. (2003). Teachers, technology and training: Online learning in virtual high school. International Journal of Instructional Media, 30(2), 117-121.

Ferdig, M. A. (2007). Sustainability leadership: Co-creating a sustainable future. Journal of Change Management, 7(1), 25-35. https:/ / doi.org/10.1080/14697010701233809

Figueroa, F., Figueroa, D., Calvo-Mena, R., Narvaez, F., Medina, N., \& Prieto, J. (2020). Orthopedic surgery residents' perception of online education in their programs during the COVID-19 pandemic: Should it be maintained after the crisis? Acta Orthopaedica, 91. https://doi.org/10.1080/17453674.2020.1776461

Fogel, J., \& Nehmad, E. (2009). Internet social network communities: Risk taking, trust, and privacy concerns. Computers in Human Behavior, 25(1), 153-160. https://doi.org/10.1016/j.chb.2008.08.006

George, D., \& Mallery, P. (2003). SPSS for windows step by step: A simple guide and reference. 11.0 update. Allyn and Bacon.

Gilbert, B. (2015). Online learning revealing the benefits and challenges. Paper 3030. Education Masters. Retrieved from https://fisherpub. sjfc.edu/education_ETD_masters/303

Greene, J. A., \& Azevedo, R. (2010). The measurement of learners' self-regulated cognitive and metacognitive processes while using computer-based learning environments. $\begin{array}{lll}\text { Educational } & \text { Psychologist, } & \text { 203-209. }\end{array}$ https://doi.org/10.1080/00461520.2010.515935

Goh, P. S., \& Sandars, J. (2020). A vision of the use of technology in medical education after the COVID-19 pandemic. MedEdPublish, 9(1), 49. https://doi.org/10.15694/mep.2020.000049.1 
Halverson, L. R., \& Graham, C. R. (2019). Learner engagement in blended learning environments: A conceptual framework. Online Learning, 23(2), 145-178. https://doi.org/10.24059/olj.v23i2.1481

Hartini, T. I., Liliasari, A. S., \& Ramalis, T. R. (2020). Implementing analytic mechanics learning based on multiple representations on GeoGebra Software: In forwardness to face the Industrial Revolution 4.0 (Mr-Geo. 4ir). Journal of Talent Development and Excellence, 12(1), 3940-3954. https:// doi.org/10.1088/1742-6596/1572/1/012015

Kalpokaite, N., \& Radivojevic, I. (2019). Teaching qualitative data analysis software online: a comparison of face-to-face and e-learning ATLAS. ti courses. International Journal of Research \& Method in Education, 43(3), 296-310. https://doi.org/10.1080/1743727X.2019.1687666

Kara, M., Erdoğdu, F., Kokoç, M., \& Cagiltay, K. (2019). Challenges faced by adult learners in online distance education: A literature review. Open Praxis, 11(1), 5-22. https://doi.org/10.5944/openpraxis.11.1.929

Kelentrić, M., Helland, K., \& Arstorp, A. T. (2017). Professional digital competence framework for teachers. The Norwegian Centre for ICT in Education, 1-74.

Mahama, A. (2016). Challenges facing internet connectivity: Perspectives of private cyber cafes. International Journal of Scientific Engineering and Applied Science, 2(2), 466-474.

Morgan, K. (25 July 2015). The pros $\mathcal{E}$ cons of cell phone usage in college. Education Web. http://education.seattlepi.com/pros-cons-cell-phone-usage-college-1578.html

Narh, N., Boateng, R., Afful-Dadzie, E., \& Owusu, A. (2019, August). Virtual platforms: Assessing the challenges of e-learning in Ghana [Paper presentation]. The Twentyfifth Americas Conference on Information Systems, Cancun, Mexico.

Ogbonnaya, U. I. (2019). Adoption and perceived usefulness of social media by pre-service teachers in Nigeria. International Journal of Interactive Mobile Technologies, 13(6), 5267. https://doi.org/10.3991/ijim.v13i06.10299

Orlando, J., \& Attard, C. (2015). Digital natives come of age: The reality of today's early career teachers using mobile devices to teach mathematics. Mathematics Education Research Journal, 28, 107-121. https://doi.org/10.1007/s13394-015-0159-6

Radha, R., Mahalakshmi, K., Kumar, V. S., \& Saravanakumar, A. R. (2020). E-Learning during lockdown of Covid-19 pandemic: A global perspective. International Journal of Control and Automation, 13(4), 1088-1099.

Roper, A. R. (2007). How students develop online learning skills. EDUCAUSE Quarterly, 30(1), 62-65. https://www.vistacampus.gov/system/files/ legacy/37/VISTABlend/documents/how_students_develop_online_learning_sk ills. pdf

Rose, S. (31 March, 2020). Medical student education in the time of COVID-19. JAMA Network. https://doi.org/10.1001/jama.2020.5227

Shea, P., \& Bidjerano, T. (2014). Does online learning impede degree completion? A national study of community college students. Computers $\mathcal{E}$ Education, 75, 103-111.

Straub, E. T. (2009). Understanding technology adoption: Theory and future directions for informal learning. Review of Educational Research, 79(2), 625-649. https:// doi.org/10.3102/0034654308325896

Tanabe, J. (2020). Exploring a post-COVID-19 sustainable peace model. Social Ethics Society. Journal of Applied Philosophy, 6(2), 73-103.

Tang, E., \& Lam, C. (2014). Building an effective online learning community (OLC) in blogbased teaching portfolios. The Internet and Higher Education, 20, 79-85. https://doi.org/10.1016/j.iheduc.2012.12.002

Thomas, P. Y. (2010). Towards developing a web-based blended learning environment at the University of Botswana [Doctoral dissertation, University of South Africa]. 
Thompson, D. L. (2010). Beyond the classroom walls: Teachers' and students' perspectives on how online learning can meet the needs of gifted students. Journal of Advanced Academics, 21(4), 662-712. https:// doi.org/10.1177/1932202x1002100405

Traxler, J. (2018). Distance learning - predictions and possibilities. Education Sciences, 8(1), 1-13. https://doi.org/10.3390/educsci8010035

Vygotsky, L. S. (1962). Language and thought. Massachusetts Institute of Technology Press. Waisbord, S. (2019). Communication: A post-discipline. Polity Press.

Watson, J. (2008). Blended learning: The convergence of online and face-to-face education. promising practices in online learning. North American Council for Online Learning.

Yen, C., Tu, C., Sujo-Montes, L., \& Sealander, K. (2016). A predictor for PLE management: Impacts of self-regulated online learning on students' learning skills. Journal of Educational Technology Development and Exchange, 9(1), 29-48. https://doi.org/10.18785/jetde.0901.03

Zimmerman, B. J. (2002). Becoming a self-regulated learner: An overview. Theory into Practice, 41(2), 64-70. 


\section{Data Collection Instrument}

\section{Student Online Learning Experience Questionnaire}

This questionnaire is designed to obtain information about your online learning due to the COVID-19 pandemic. There are no right, or wrong answers and your response will be anonymous, and the information gathered will be used for academic purposes only.

We thank you in advance for taking out your time to complete the questionnaire. It will take you about 10 minutes to complete.

\section{Demographic data}

\section{Gender: \\ Male}

Age:

$$
15 \text {-20 years }
$$

Female

$21-25$ years $26-30$ years

\section{$31-40$ years}

\section{Engagement with online learning}

How would you rate your own Digital Literacy?

- Excellent

- Very good

- Good

- Adequate

- Limited

- Poor

- Not sure

Which of the following devices do you use for online learning?

- Desktop

- Laptop

- Tablet

- iPad

- Smartphone

Which of the following devices do you personally own?

- Desktop

- Laptop

- Tablet

- iPad

- Smartphone

How do you connect to the internet for your online learning?

- Wi-Fi

- Modem

- smartphone

- Cell phone hotspot

About how many hours of online lectures do you receive weekly?

$1-2$ hours

\begin{tabular}{|l|}
\hline $3-4$ \\
hours \\
\hline
\end{tabular}

\begin{tabular}{|l|}
\hline $5-6$ \\
hours \\
\hline
\end{tabular}

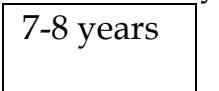

More than 8 hours

About how many hours did you spend on your own learning online daily?

\begin{tabular}{|c|c|c|c|c|}
\hline 1 - 2 hours & $\begin{array}{l}3-4 \\
\text { hours }\end{array}$ & $\begin{array}{l}5-6 \\
\text { hours }\end{array}$ & 7-8 years & More than 8 hours \\
\hline
\end{tabular}


List the online platforms you used for online learning (e.g. Zoom, Screencast, WhatsApp, Sakai, google meet, etc.)

Which tools did you find most valuable for online learning (e.g. chartroom, Forum, commons, collaborate, clickup, test and quizzes, etc.)?

\section{Statements about online learning}

\begin{tabular}{|c|c|c|c|c|c|}
\hline & & $\begin{array}{l}\text { Strongly } \\
\text { Agree }\end{array}$ & Agree & Disagree & $\begin{array}{l}\text { Strongly } \\
\text { Disagree }\end{array}$ \\
\hline 1. & $\begin{array}{l}\text { I could easily access the Internet as needed for my } \\
\text { studies. }\end{array}$ & & & & \\
\hline 2. & I am comfortable communicating online & & & & \\
\hline 3. & $\begin{array}{l}\text { I am willing to actively communicate with my } \\
\text { classmates online }\end{array}$ & & & & \\
\hline 4. & $\begin{array}{l}\text { I am willing to actively communicate with my } \\
\text { lecturers online }\end{array}$ & & & & \\
\hline 5. & I find it easy to set aside time for learning online & & & & \\
\hline 6. & I could manage my online learning time effectively. & & & & \\
\hline 7. & $\begin{array}{l}\text { I could easily complete my online assignments on } \\
\text { time. }\end{array}$ & & & & \\
\hline 8. & I enjoy online learning & & & & \\
\hline 9. & I enjoy working with other students in online groups & & & & \\
\hline 10. & $\begin{array}{l}\text { I have enough computer skills for doing online } \\
\text { learning. }\end{array}$ & & & & \\
\hline 11. & I feel comfortable communicating online & & & & \\
\hline 12. & $\begin{array}{l}\text { I feel comfortable to ask my lecturers questions } \\
\text { during online learning activities }\end{array}$ & & & & \\
\hline 13. & $\begin{array}{l}\text { I receive a quick response during online learning } \\
\text { activities }\end{array}$ & & & & \\
\hline 14. & $\begin{array}{l}\text { I feel that face-to-face contact with my lecturers is } \\
\text { necessary to learn }\end{array}$ & & & & \\
\hline 15. & $\begin{array}{l}\text { I can discuss with other students during online } \\
\text { learning activities }\end{array}$ & & & & \\
\hline 16. & $\begin{array}{l}\text { I can collaborate with other students during online } \\
\text { learning activities }\end{array}$ & & & & \\
\hline 17. & $\begin{array}{l}\text { Online learning is as good as face to face class } \\
\text { learning }\end{array}$ & & & & \\
\hline 18. & $\begin{array}{l}\text { I believe that learning online is more motivating than } \\
\text { face to face learning }\end{array}$ & & & & \\
\hline 19. & $\begin{array}{l}\text { I believe a complete course can be taught online } \\
\text { without any difficulty. }\end{array}$ & & & & \\
\hline 20. & $\begin{array}{l}\text { I can pass a course online without any face to face } \\
\text { class lecture }\end{array}$ & & & & \\
\hline 21. & $\begin{array}{l}\text { I found it difficult to adjust to the online learning } \\
\text { context }\end{array}$ & & & & \\
\hline 22. & Online learning encouraged the exchange of ideas & & & & \\
\hline 23. & Online learning enhanced my learning & & & & \\
\hline
\end{tabular}


Explain some of your positive experiences of the online learning

Explain some of the challenges you had learning online 